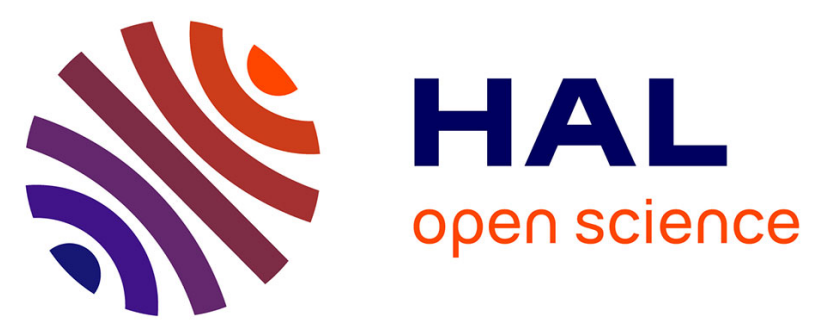

\title{
On the Thermo-Hydro-Mechanical Behaviour of a Sheared Callovo-Oxfordian Claystone Sample with Respect to the EDZ Behaviour
}

Hamza Menaceur, Pierre Delage, Anh Minh A.M. Tang, Nathalie Conil

\section{To cite this version:}

Hamza Menaceur, Pierre Delage, Anh Minh A.M. Tang, Nathalie Conil. On the Thermo-HydroMechanical Behaviour of a Sheared Callovo-Oxfordian Claystone Sample with Respect to the EDZ Behaviour. Rock Mechanics and Rock Engineering, 2016, 49 (5), pp.1875-1888. 10.1007/s00603-0150897-5 . hal-01271319

HAL Id: hal-01271319

https://hal-enpc.archives-ouvertes.fr/hal-01271319

Submitted on 9 Feb 2016

HAL is a multi-disciplinary open access archive for the deposit and dissemination of scientific research documents, whether they are published or not. The documents may come from teaching and research institutions in France or abroad, or from public or private research centers.
L'archive ouverte pluridisciplinaire HAL, est destinée au dépôt et à la diffusion de documents scientifiques de niveau recherche, publiés ou non, émanant des établissements d'enseignement et de recherche français ou étrangers, des laboratoires publics ou privés. 


\title{
On the Thermo-Hydro-Mechanical Behaviour of a Sheared Callovo-Oxfordian Claystone Sample with Respect to the EDZ Behaviour
}

\author{
Hamza Menaceur ${ }^{1} \cdot$ Pierre Delage $^{1} \cdot$ Anh Minh Tang ${ }^{1} \cdot$ Nathalie Conil $^{2}$
}

Received: 10 September 2014/ Accepted: 1 December 2015

(C) Springer-Verlag Wien 2015

\begin{abstract}
To better understand the impact of temperature elevation on the response of the excavation damaged zone around repository cells and galleries for radioactive waste disposal, the combined effects of shear and temperature elevation were investigated in the laboratory on the Callovo-Oxfordian claystone. To do so, a hollow cylinder thermal triaxial cell with short drainage path specifically developed for low permeability rocks was used. Once properly saturated under stress conditions close to in situ, the specimen was sheared along a constant effective mean stress path mimicking the stress path followed during gallery excavation. The shear stress was afterwards released and an undrained heating test was performed on the sheared specimen. It was observed that the temperature increase under undrained conditions led to a thermal increase in pore water pressure resulting in a decrease in mean effective stress that brought back the sheared specimen to failure, evidencing a thermally induced failure. Steady state radial permeability tests performed at various stages of the test demonstrated that the overall permeability of the sheared specimen was comparable to that before shearing, confirming the excellent self-sealing properties of the Callovo-Oxfordian claystone. This shows that, in spite of being possibly remobilised by temperature elevation, the EDZ will keep an overall permeability constant equal to that of the massive rock, keeping the same isolation properties.
\end{abstract}

Pierre Delage

delage@cermes.enpc.fr

1 Laboratoire Navier/CERMES, Ecole des Ponts ParisTech, 6-8 av. Blaise Pascal, 77455 Marne-la-Vallee, France

2 ANDRA, Chatenay-Malabry, France
Keywords Claystone $\cdot$ Permeability - Excavation damaged zone $\cdot$ Shear band $\cdot$ Undrained heating $\cdot$ Self sealing

\section{Introduction}

The Callovo-Oxfordian (COx) claystone has been selected as a potential host rock for deep geological repository of high-level radioactive waste in France because of its low permeability, good self sealing properties and good radionuclide adsorption capacity. The host rock around the repository cells containing the exothermic waste canisters will be submitted to various coupled mechanical, hydraulic and thermal phenomena including the development of an excavation damaged zone (EDZ) that might affect the overall rock permeability in the close field (Armand et al. 2014). The heat emitted by the high-level radioactive waste will increase temperature in the host rock, with a maximum admitted temperature of $90{ }^{\circ} \mathrm{C}$ around the waste canisters in the French concept (ANDRA 2012). This temperature elevation might have some effects on the crack network of the EDZ. This problem was investigated in the framework of the TIMODAZ European research project devoted to the "Thermal Impact on the Damaged Zone around a radioactive waste disposal in clay host rocks" ( $\mathrm{Li}$ et al. 2014). The temperature elevation might also lead to an increase in pore pressure and a decrease in effective stress in the EDZ due to thermal pressurisation (Mohajerani et al. 2012), resulting in possible thermo-mechanical failure (Hueckel and Pellegrini 1991; Hueckel et al. 2009). In this context, Monfared et al. (2012) investigated the thermal reactivation of a pre-existing shear band in undrained conditions in the Boom clay. 
The effects of cracks on water transfers have been investigated by various authors in various clays and claystones. The experimental investigation of Zhang (2011) on fractured COx and Opalinus clay specimens showed that the permeability of fractured specimens decreased significantly by several orders of magnitude upon hydration of the cracks, thanks to the hydration of the smectite minerals in the clay matrix that resulted in clogging the fractures. Davy et al. (2007) also observed that the permeability of a confined cylindrical COx specimen containing an artificial crack made by previously carrying out a Brazilian tensile test was comparable to that of the intact claystone. Comparable conclusions were drawn by Zhang (2011) on the Opalinus clay and the COx claystone and by Monfared et al. (2012) on the Boom clay, confirming their good self sealing capacity.

The effects of heating on the permeability of intact clays have been investigated by Morin and Silva (1984); Delage et al. (2000); Zhang (2013), among others. Data showed that the change in water transfer with temperature was only due to the changes in water viscosity, resulting in a constant intrinsic permeability with respect to temperature changes. This has been recently confirmed in the COx claystone as well by Menaceur et al. (2015). Note however that available literature data on the effects of temperature on the permeability of damaged clays and claystones materials are scarce. Recently, Monfared et al. (2014) showed that the intrinsic permeability of a sheared Opalinus clay specimen remained almost equal to that of intact specimens at both 25 and $80^{\circ} \mathrm{C}$, confirming the good selfsealing properties of the Opalinus clay at elevated temperature.

The present work aims at investigating the effect of temperature elevation on a $\mathrm{COx}$ claystone specimen previously damaged by a shear test that resulted in the development of a network of shear planes, following the approach followed by Monfared et al. (2012) on the Boom clay. Once sheared, the shear stress was released prior to reactivate the shear bands by temperature elevation. Permeability tests run at various stages of the test allowed to monitor possible changes in permeability due to damage and temperature elevation. To do so, a thermal hollow cylinder triaxial cell recently developed for this purpose (Monfared et al. 2011a) was used. The two main characteristics of this device are, on the one hand, a short drainage path (half the thickness of the cylinder) allowing for good saturation and drainage conditions and, on the other hand, the possibility of running radial permeability tests at various temperatures by establishing a water flow between the inner and outer faces of the hollow cylinder through the shear plane network.

\section{Materials and Methods}

\subsection{The Callovo-Oxfordian Claystone}

The Callovo-Oxfordian claystone is a marine sediment from the Jurassic period, deposited 160 millions years ago between the Callovian and the Oxfordian ages in the western area of the Parisian basin. It has been since that time submitted to various significant tectonic effects including some horizontal stresses resulting from the Alpine orogenese.

The mineralogical composition of the COx claystone varies with depth with significant changes in carbonate and clay contents. The COx total connected porosity varies between $14 \%$ in carbonated levels and $19.5 \%$ in more argillaceous levels (Yven et al. 2007). At the Underground Research Laboratory (URL) at Bure, Eastern France, the formation (at $490 \mathrm{~m}$ depth) is relatively homogenous and made up of a clay matrix containing carbonates, quartz and accessory minerals. The clay fraction $(45-50 \%)$ is made up of mixed layers of interstratified illite/smectite (20-24\%) and illite (17-21\%) with also small amounts of kaolinite and chlorite. It also contains $20 \%$ calcite, $22 \%$ quartz and $9 \%$ of various other minerals such as feldspars, pyrite, dolomite, siderite and phosphate (Gaucher et al. 2004). The smectite percentage in the clay fraction is responsible for the swelling and self-sealing behaviour of the COx claystone (Davy et al. 2007; Zhang and Rothfuchs 2008; Mohajerani et al. 2011).

In the present work, an experiment was performed on a hollow cylinder specimen taken from a core (EST30734) perpendicular to the bedding, extracted at the same level as that of the URL. The specimen was carefully trimmed from $100 \mathrm{~mm}$ diameter core on a lathe. The initial characteristics of the sample are presented in Table 1. The initial gravimetric water content of the sample was $7.4 \%$. The porosity and degree of saturation were calculated by measuring the sample volume by hydrostatic weighing. The initial total suction was determined using a dew point potentiometer (WP4, Decagon). As seen in Table 1, the sample is not saturated at initial state with a degree of saturation of $94 \%$ corresponding to a suction of 6.1 MPa with a porosity of $17.5 \%$. The partial saturation of the specimen resulted from the combined actions of coring, transport, storage and trimming.

\subsection{Experimental Device}

The hollow cylinder triaxial cell specially designed (Monfared et al. 2011a) to investigate the thermo-hydromechanical behaviour of low permeability clays and claystones was used. A global overview of the cell is 
Table 1 Initial characteristics of the tested sample

\begin{tabular}{lllllll}
\hline & Height $(\mathrm{mm})$ & Water content $(\%)$ & Degree of saturation $(\%)$ & Porosity $(\%)$ & Dry unit mass $\left(\mathrm{mg} / \mathrm{m}^{3}\right)$ & Suction $(\mathrm{MPa})$ \\
\hline EST30734 & 73.37 & 7.4 & 94 & 17.5 & 2.23 & 6.1 \\
\hline
\end{tabular}

presented in Fig. 1a, that schematically shows the hollow cylinder specimen (external diameter $\varphi_{\text {ext }}=100 \mathrm{~mm}$, internal diameter $\varphi_{\text {int }}=60 \mathrm{~mm}$, height $h=70-80 \mathrm{~mm}$ ) inside the triaxial cell. The same confining pressure is applied along both the external and internal lateral faces of the sample. As shown in Fig. 1a, b, a major advantage of this device is the presence of two lateral drainages in the inner and the outer walls of the hollow cylinder sample made up of two geotextile bands placed along the sample with no connection with the upper and lower drainages. These lateral drainages reduce the specimen drainage length down to half of the thickness of the hollow cylinder $(10 \mathrm{~mm})$. They also allow carrying out radial permeability tests so as to capture the effects of shear bands on the soil's permeability. Compared to standard full cylinder triaxial samples with drainage at top and bottom ends, the short drainage path allows reducing the time needed to fully resaturate an initially unsaturated claystone sample by a factor of seven (Monfared et al. 2011a). Also, satisfactory drainage conditions are achieved during mechanical and thermal loading provided the strain rate and temperature elevation rate are small enough.
Figure $1 \mathrm{~b}$ also shows a schematic view of the hydraulic connections between the sample, the pressure-volume controllers (PVC) and the pressure transducers (PT). PVC1 is used to apply the confining pressure whereas the other three PVCs are used to apply and control the pore fluid pressure. The device is also equipped with two axial and four radial local displacement transducers (LVDTs, accuracy $\pm 1 \mu \mathrm{m})$ to monitor local strains. The heating system consists of a heating electric belt placed around the cell with a temperature regulator with an accuracy of $\pm 0.1{ }^{\circ} \mathrm{C}$. Temperature is measured inside the cell close to the sample by a thermocouple. An insulating layer covers the cell to limit heat exchanges with the surrounding environment.

The shear stress is applied using an integrated piston specially developed and manufactured (Fig. 1c). This piston is hydraulically activated by a pressure-volume controller (maximum pressure of $60 \mathrm{MPa}$ ). As shown in Fig. 1c, the piston is connected to the PVC, which controls the movement of the piston and thus applies the shear stress. The applied force is directly measured by a local immersed force sensor installed at the end of the piston.
Fig. 1 a Hollow cylinder triaxial cell, $\mathbf{b}$ general setting of the connections with the pressure volume controllers (PVC), c system for applying deviatoric stress
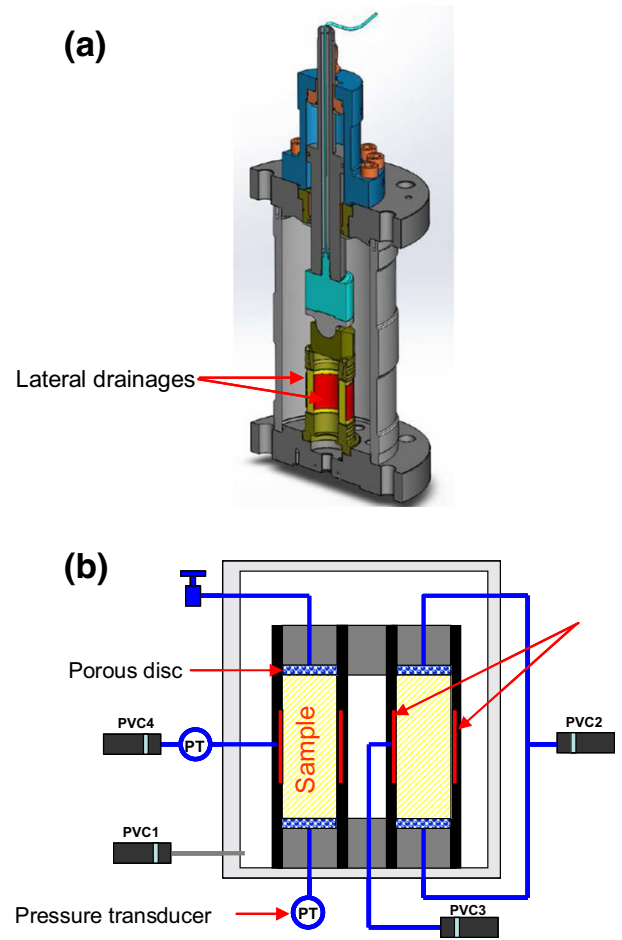

(c)

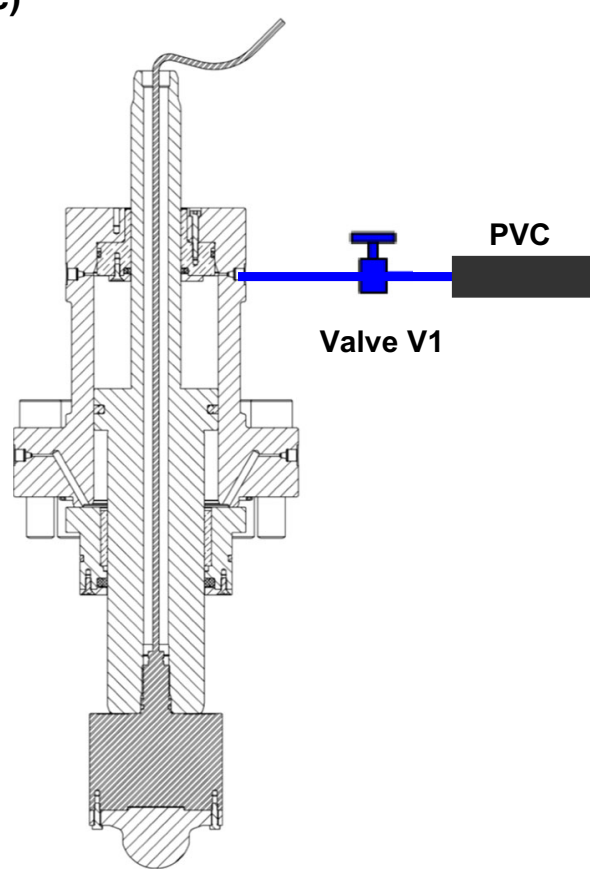




\subsection{Sample Resaturation}

As shown by Monfared et al. (2011a), an interesting feature of the hollow cylinder triaxial cell is to ensure good initial saturation of samples of very low permeability (around $10^{-20} \mathrm{~m}^{2}$ in the case of the COx claystone) within a reasonable period of time, thanks to a reduced drainage path. As recalled by Delage et al. (2007) on the Boom Clay, Monfared et al. (2011b) on the Opalinus clay and Mohajerani et al. (2011) on the COx claystone, it is important to re-saturate specimens of swelling clays under stress conditions close to the in situ ones to avoid further perturbation due to swelling during hydration.

The in situ state of stress in the Bure URL has been investigated in detail by Wileveau et al. (2007) who provided the following values:

- Vertical total stress $\sigma_{\mathrm{v}}=12.7 \mathrm{MPa}$,

- Minor horizontal total stress $\sigma_{\mathrm{h}}=12.4 \mathrm{MPa}$,

- Major horizontal total stress $\sigma_{\mathrm{H}}=12.7-14.8 \mathrm{MPa}$,

- Pore pressure $u=4.9 \mathrm{MPa}$.

In their experiments in the hollow cylinder apparatus, Mohajerani et al. (2014) adopted stress conditions close to in situ, i.e. a confining stress of $12 \mathrm{MPa}$ and a pore pressure of $4 \mathrm{MPa}$. Under such high pressures, perforation of the neoprene jacket resulting in test failure in various occasions. To avoid this problem, it was decided here to carry out the tests at lower stress and pore pressure, keeping the same Terzaghi effective stress of $8 \mathrm{MPa}$ but with a confining pressure of $9 \mathrm{MPa}$ and a pore pressure to $1 \mathrm{MPa}$. This was done in a purpose of simplicity given the uncertainty about the value of the Biot parameter $b$ for the COx claystone, with published values between 0.3 and 0.8 depending on the confining stress (see for instance Bemer et al. 2004) and with a value of 0.6 generally adopted in calculations (e.g. Gens et al. 2007). Actually, with a $b$ value of 0.6 , the Biot effective stress corresponding to a confining stress of $12 \mathrm{MPa}$ with a pore pressure of $4 \mathrm{MPa}$ would be equal to $9.6 \mathrm{MPa}$. With a confining pressure of $9 \mathrm{MPa}$ and a pore pressure of $1 \mathrm{MPa}$, the Biot effective stress is smaller at $8.4 \mathrm{MPa}$. This difference, that would be smaller with higher Biot coefficient, shows that the conditions applied here are less close to in situ stress conditions than that applied by Mohajerani et al. (2014). Better stress conditions could be achieved once knowing the exact value of the Biot parameter under the in situ stress conditions.

Another issue is related to the effect of the back pressure level on the quality of saturation. The conditions here are probably less favourable that that adopted by Mohajerani et al. (2014) given that air dissolution in water is enhanced under higher back-pressure.

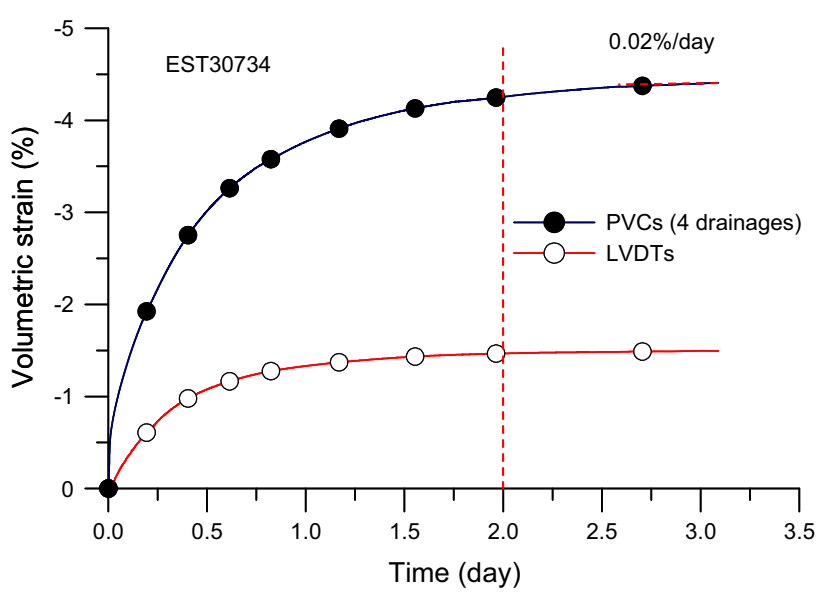

Fig. 2 Volume changes and water exchanges during saturation

Once applied the confining stress, specimen saturation was carried out by injecting demineralised water from the back-pressure PVC, allowing to get back to the initial salt concentration of the pore water.

Figure 2 shows the volume changes calculated from the water injected from the PVC compared to that monitored by local LVDT measurements during the saturation phase. The two curves show a stabilisation after 2 days. A swelling rate of $0.02 \% /$ day is afterwards obtained from both the LVDT measurements and the volume of water injected. The higher total volume obtained from the injected water is related the saturation of the soil specimen and of the porous elements of the drainage system (upper and lower porous discs, lateral geotextiles).

\subsection{Radial Permeability Tests}

Steady state radial permeability tests were carried out by applying a pressure difference between the outer and the inner lateral faces of the hollow cylinder specimen and by measuring the inflow and outflow water fluxes using the PVCs. This procedure is particularly adapted to investigate the effects of shear bands on the permeability of sheared hollow cylinder specimens. Permeability tests were carried out on a specimen submitted to an initial back pressure of 1.0 $\mathrm{MPa}$ by closing the valves connected to the top and bottom of the sample and by applying a pressure of 1.5 MPa through the external geotextile while maintaining the pressure in the internal geotextile equal to $1.0 \mathrm{MPa}$. Tests were carried out using demineralised water to avoid any corrosion of the PVCs. This is not optimum given that the salt concentration is then modified. A procedure using an interface cell transmitting the pressure exerted by the PVC on demineralised water to synthetic water would have been preferable but it could not be developed in this study. 
In a standard fashion, the radial intrinsic permeability $k_{\mathrm{r}}$ $\left(\mathrm{m}^{2}\right)$ was calculated using the flow rates as follows:

$k_{\mathrm{r}}=\frac{Q_{\mathrm{p}} \mu_{\mathrm{w}} \ln \left(R_{\mathrm{ext}} / R_{\mathrm{int}}\right)}{2 \pi h \Delta u}$

where $Q_{\mathrm{p}}$ is the water flow; $\mu_{\mathrm{w}}$ the water viscosity (equal to $8.90 \times 10^{-4} \mathrm{~Pa} \mathrm{~s}$ at $25^{\circ} \mathrm{C}$ and $3.55 \times 10^{-4} \mathrm{~Pa}$.s at $\left.80^{\circ} \mathrm{C}\right)$, $R_{\text {ext }}$ and $R_{\text {int }}$ the external and internal sample radius, respectively $\left(R_{\text {ext }}=50 \mathrm{~mm} ; R_{\text {int }}=30 \mathrm{~mm}\right) ; h$ the flow height $(h=50 \mathrm{~mm})$; and $\Delta u$ is the pressure difference between the inner and outer walls of the sample $(\Delta u=0.5 \mathrm{MPa})$.

\subsection{Experimental Programme}

The sample was tested along a thermo-hydro-mechanical path aimed at reproducing the stress state in the close field of the excavated gallery. The path followed is shown in Fig. 3. The test was aimed at investigating the possibility of reactivating a shear band by thermal pressurisation and at capturing the effect of the shear band formation on the radial permeability.

Once resaturated close to the in situ stress state (point B in Fig. 3), the sample was sheared at $25^{\circ} \mathrm{C}(\mathrm{B}-\mathrm{C})$ in drained conditions along a constant mean effective stress $p^{\prime}$ path. The axial deformation was afterwards kept constant, resulting in a release in shear stress $q(\mathrm{C}-\mathrm{D})$ during the radial permeability test at point $\mathrm{C}$. Then, the sheared sample was heated at $80{ }^{\circ} \mathrm{C}$ in undrained conditions (D-E). Finally, the cell temperature was reduced to $25^{\circ} \mathrm{C}$ and the stress state was set at isotropic condition (point $\mathrm{F}$ : $p=6.6 \mathrm{MPa}$ ) prior to running a drained heating test. Radial steady state permeability tests were carried out after initial resaturation [point (B)], right after shearing (C), after shear stress release (D), after heating the sheared sample up

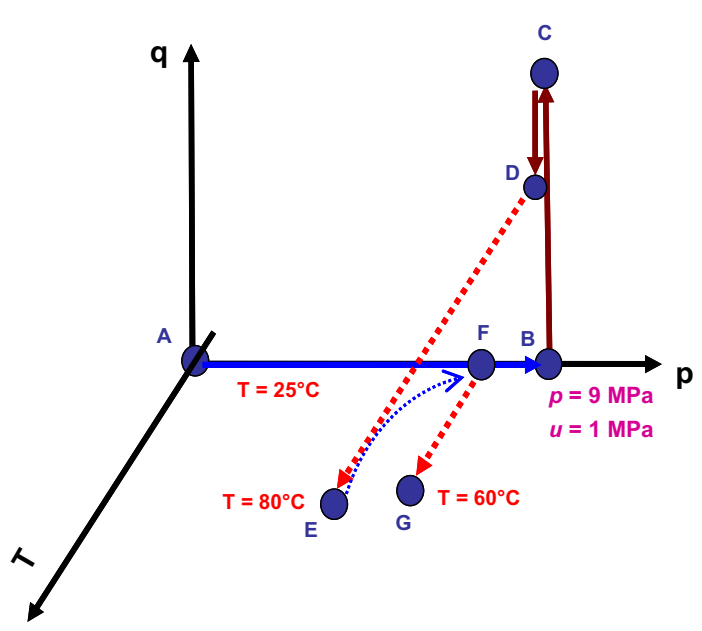

Fig. 3 Schematic view of the THM loading paths followed to $80{ }^{\circ} \mathrm{C}(\mathrm{E})$ and after cooling the sheared sample down to $25{ }^{\circ} \mathrm{C}(\mathrm{F})$.

\section{Experimental Results}

\subsection{Initial Radial Permeability (Point B)}

Two permeability tests were performed at point B to check the repeatability of the procedure. The water exchanges monitored by the upstream and downstream PVCs during the first test are presented in Fig. 4a. The axial and radial strains obtained from the local LVDT measurements are plotted in Fig. 4b, c, with an almost similar response observed for measurements in the same direction. Figure $4 \mathrm{~d}$ shows the changes in specimen volume during the test, calculated from both the water exchanges monitored by the upstream and downstream PVCs and the local LVDT measurements. Good correspondence is observed between these two independent measurements, bringing confidence in their quality and in the water tightness of the system. The volume changes curves from LVDTs also show that after a transient infiltration phase during the first $10 \mathrm{~h}$, a constant infiltration rate of $1.2 \times 10^{-3} \% \mathrm{~h}^{-1}$ is afterwards observed. This trend is typical of swelling clays and claystones and has already been observed by Monfared et al. (2011b) on the Opalinus clay, Mohajerani et al. (2011) on the COx claystone and, on the Boom clay, by Cui et al. (2009), Monfared et al. (2012) and Bésuelle et al. (2014).

The flow curves of Fig. 4a show that the upstream PVC injects water (at $1.5 \mathrm{MPa}$ ) into the sample (initial back pressure $1 \mathrm{MPa}$ ) from the beginning of the test, as expected. However, one observes that it is necessary to wait for $3.5 \mathrm{~h}$ before monitoring any outflow with the downstream PVC. Also, the downstream PVC indicates the occurrence of water infiltration into the sample during the 3 first hours through the internal phase submitted to the smallest $1 \mathrm{MPa}$ pressure. Combined observation of Fig. 4a, d shows that this infiltration through the downstream face corresponds to the transient phase of the swelling process observed in Fig. 4d. This transient swelling phase is due to the release of the effective stress profile along the radial path followed by the water flow due to the application of the $1.5 \mathrm{MPa}$ pressure along the outer face of the sample. Once this transient phase completed, a steady phase occurs with some injected water kept within the sample, explaining the difference between the outflow and inflow after $25 \mathrm{~h}$ in Fig. 4a.

Given that swelling still goes on at the end of the test (after $30 \mathrm{~h}$ ), the permeability calculation cannot be made from inflow and outflow data without considering the part of the flow taken to hydrate the swelling clay fraction. It is 

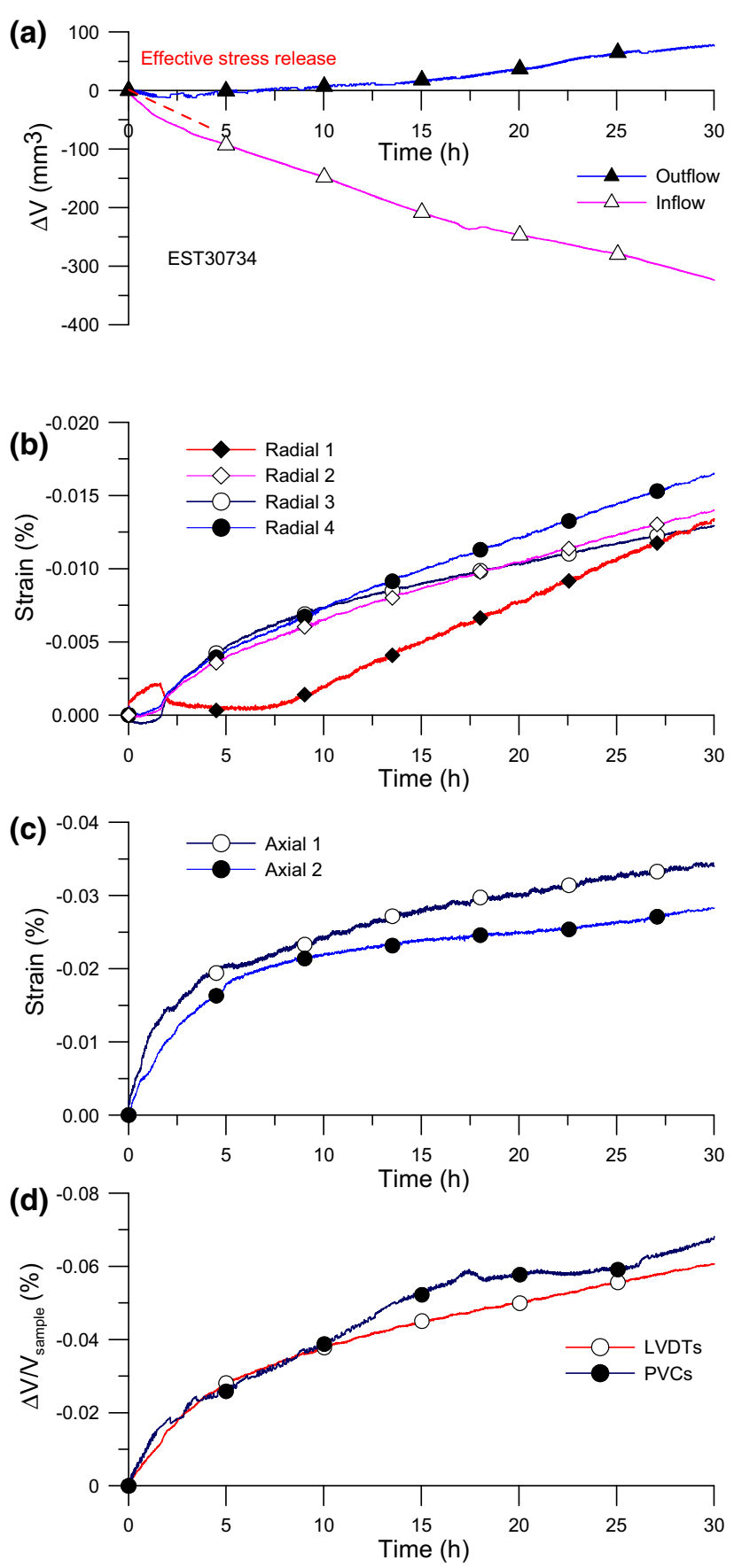

Fig. 4 Radial steady state permeability test at point B (first test), $\mathbf{a}$ inflow and outflow, $\mathbf{b}$ radial strains, $\mathbf{c}$ axial strains, $\mathbf{d}$ volume change

proposed to consider that this part of hydrating water comes from both upstream and downstream flows. If one denotes the flow contributing to clay hydration as $Q_{\mathrm{s}}$ and that contributing to water transfer and permeability as $Q_{\mathrm{p}}$ and under the (strong) hypothesis of having the same contribution to swelling from both inflow and outflow, the inner and outer flows $\left(Q_{\mathrm{i}}\right.$ and $Q_{\mathrm{p}}$ respectively) can be written as:
$Q_{\mathrm{i}}=Q_{\mathrm{p}}+Q_{\mathrm{s}} / 2$

$Q_{\mathrm{o}}=Q_{\mathrm{p}}-Q_{\mathrm{s}} / 2$

providing the following value of $Q_{\mathrm{p}}$ :

$Q_{\mathrm{p}}=\frac{Q_{\mathrm{i}}+Q_{\mathrm{o}}}{2}$

However, observation of the slope of the inflow and outflow curves in Fig. 4 and in other Figures indicates that at the beginning, the infiltration rate is significantly larger upstream than downstream, with a ratio of the slopes close to 4 . This is due to the larger release in effective stress of $0.5 \mathrm{MPa}$ on the inflow side along which a back-pressure of $0.5 \mathrm{MPa}$ is applied. It seems then appropriate to consider that the inflow contribution to swelling is $n$ times larger than the outflow one. The same calculations as above leads to the following expression:

$Q_{\mathrm{p}}=\frac{Q_{\mathrm{i}}+n Q_{\mathrm{o}}}{n+1}$

in which $n$ is taken equal to 4 .

The sensitivity of the calculated permeability to the $n$ value is examined in Table 2 by comparing results with $n=1$ and 4 . Table also contains the calculations for the other permeability tests carried out. Table shows that the calculated permeability values are not very sensitive to the value of $n$. It is proposed to adopt the value obtained with $n=4$, giving a value of radial permeability of $3.2 \times 10^{-21} \mathrm{~m}^{2}$.

In the second test run under same conditions some time later, Fig. 5a shows comparable response in terms of inflow and outflow curves during the transient initial phase. However, as seen in Fig. 5b, volume change stabilisation is observed after $10 \mathrm{~h}$ with no steady state swelling as observed previously and no water mobilised for clay hydration. The same permeability value $\left(5 \times 10^{-21} \mathrm{~m}^{2}\right)$ is obtained for $n=1$ or 4 , slightly higher than previously.

\subsection{Shearing Under Constant Effective Mean Stress at Drained Conditions (Path B-C)}

Once resaturated under in situ stress state at $25^{\circ} \mathrm{C}$, the sample was loaded with a constant axial displacement rate of $0.35 \mu \mathrm{m} / \mathrm{min}$ (chosen low enough to ensure drained conditions, see Monfared et al. 2011a) while maintaining the mean stress constant. This was achieved by controlling the change in confining pressure $\left(\Delta \sigma_{3}\right)$ following the relation $\Delta \sigma_{3}=-\frac{\Delta q}{3}$ (where $q$ is the shear stress $\sigma_{1}-\sigma_{3}$ ). The changes in axial, radial and volumetric strains with respect to shear stress are presented in Fig. 6. One observes that the shear stress reaches a maximum value of $11 \mathrm{MPa}$ at $0.52 \%$ of axial strain and $-0.25 \%$ of radial strain. Note however that strain localisation is suspected to start 
Table 2 Effect of the shear loading and heating on COx claystone permeability (EST30734)

\begin{tabular}{|c|c|c|c|c|c|c|}
\hline & $Q_{\mathrm{i}}\left(\mathrm{m}^{3} / \mathrm{s}\right)$ & $Q_{\mathrm{o}}\left(\mathrm{m}^{3} / \mathrm{s}\right)$ & $Q_{\mathrm{p}}=\frac{Q_{\mathrm{i}}+Q_{\mathrm{o}}}{2}$ & $Q_{\mathrm{p}}^{*}=\frac{Q_{\mathrm{i}}+4 Q_{\mathrm{o}}}{5}$ & $k_{\mathrm{rp}}\left(\mathrm{m}^{2}\right)$ & $k_{\mathrm{rp}}^{*}\left(\mathrm{~m}^{2}\right)$ \\
\hline Before shearing, (B), 1st test & $2.51 \times 10^{-12}$ & $7.54 \times 10^{-13}$ & $1.63 \times 10^{-12}$ & $1.10 \times 10^{-12}$ & $4.72 \times 10^{-21}$ & $3.2 \times 10^{-21}$ \\
\hline Before shearing, (B), 2nd test & $1.73 \times 10^{-12}$ & $1.71 \times 10^{-12}$ & $1.72 \times 10^{-12}$ & $1.72 \times 10^{-12}$ & $4.98 \times 10^{-21}$ & $4.97 \times 10^{-21}$ \\
\hline After shearing, (C) & $6.22 \times 10^{-12}$ & $1.42 \times 10^{-12}$ & $3.82 \times 10^{-12}$ & $2.38 \times 10^{-12}$ & $11.1 \times 10^{-21}$ & $6.89 \times 10^{-21}$ \\
\hline After shearing stress release, (D) & $1.93 \times 10^{-12}$ & $1.13 \times 10^{-12}$ & $1.53 \times 10^{-12}$ & $1.29 \times 10^{-12}$ & $4.43 \times 10^{-21}$ & $3.73 \times 10^{-21}$ \\
\hline At $80^{\circ} \mathrm{C},(\mathrm{E})$ & $3.54 \times 10^{-12}$ & $1.73 \times 10^{-12}$ & $2.63 \times 10^{-12}$ & $2.09 \times 10^{-12}$ & $3.04 \times 10^{-21}$ & $2.42 \times 10^{-21}$ \\
\hline After cooling, $25^{\circ} \mathrm{C},(\mathrm{F})$ & $2.13 \times 10^{-12}$ & $5.82 \times 10^{-13}$ & $1.35 \times 10^{-13}$ & $8.92 \times 10^{-13}$ & $3.92 \times 10^{-21}$ & $2.58 \times 10^{-21}$ \\
\hline
\end{tabular}
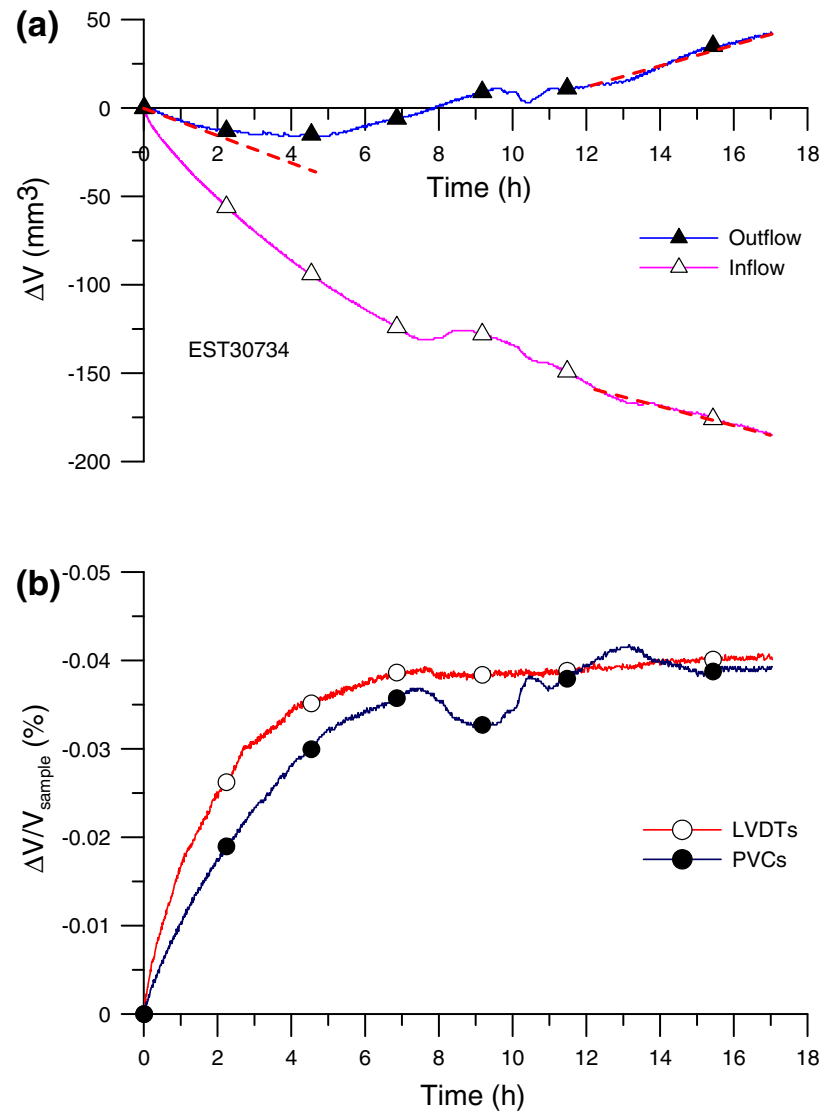

Fig. 5 Radial permeability at point B (second test), a inflow and outflow, b volume change

developing at the inflection point observed at a shear stress value of $9 \mathrm{MPa}$ of the $q / \varepsilon_{\mathrm{a}}$ stress strain curve. The section of the curves at higher shear stress has been plotted in dotted line because local displacement measurements no longer represent the homogeneous deformation of the specimen. In this regard, it is difficult to interpret the transition from dilation to contraction observed at the same $q$ value on the volume change curve. This is even truer in the post peak regime where the system is following the mutual displacements of blocks along shear planes.

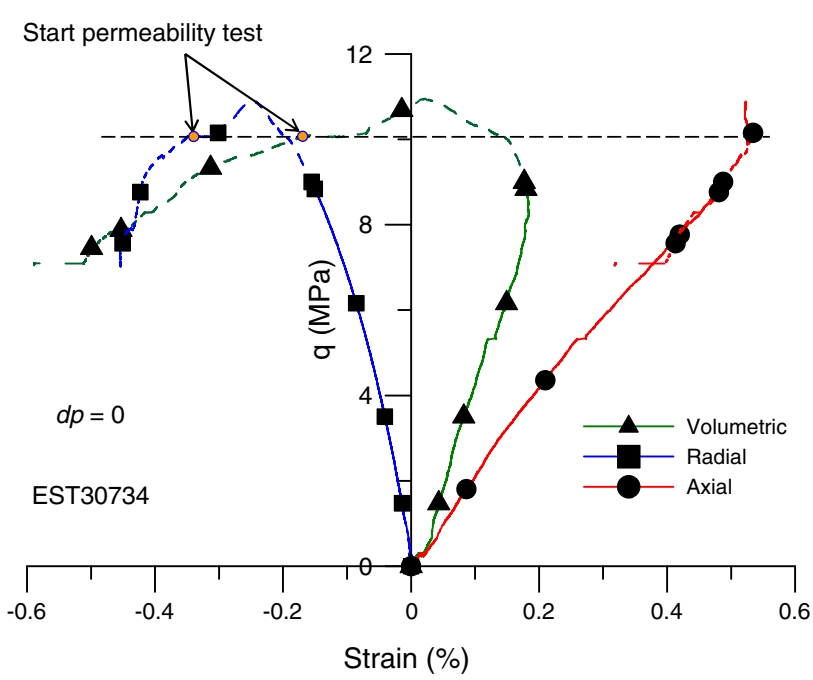

Fig. 6 Stress-strain for the shear test under constant effective mean stress at drained conditions (path B-C)

The photographs of the sample at the end of the test are presented in Fig. 7. One observes a more apparent shear band with an inclination of $67^{\circ}$ with respect to horizontal, among a network of other shear bands.

The effect of the shear bands on the overall specimen permeability was investigated by carrying out radial permeability tests after shearing at point $\mathrm{C}$, as indicated in Table 2. Once the sample sheared (point $\mathrm{C}$ ), a permeability test was carried out. As shown in Fig. 6, a decrease in shear stress took place once the permeability test started. This decrease can be related to the reactivation of shear bands due to the application of $0.5 \mathrm{MPa}$ excess pressure. Figure $8 \mathrm{a}$, which presents both the inflow and outflow curves with respect to time, shows no effect of the stress release phase, with water expelled in the downstream PVC since the beginning of the test. Figure $8 \mathrm{~b}$ shows the sample volume change during the permeability test. One observes that the volume change calculated from LVDT measurements is larger than that calculated from water exchanges because LVDT measurements incorporate both the swelling of the sample and the possible sliding of blocks along 
Fig. 7 COx specimen at the end of the test
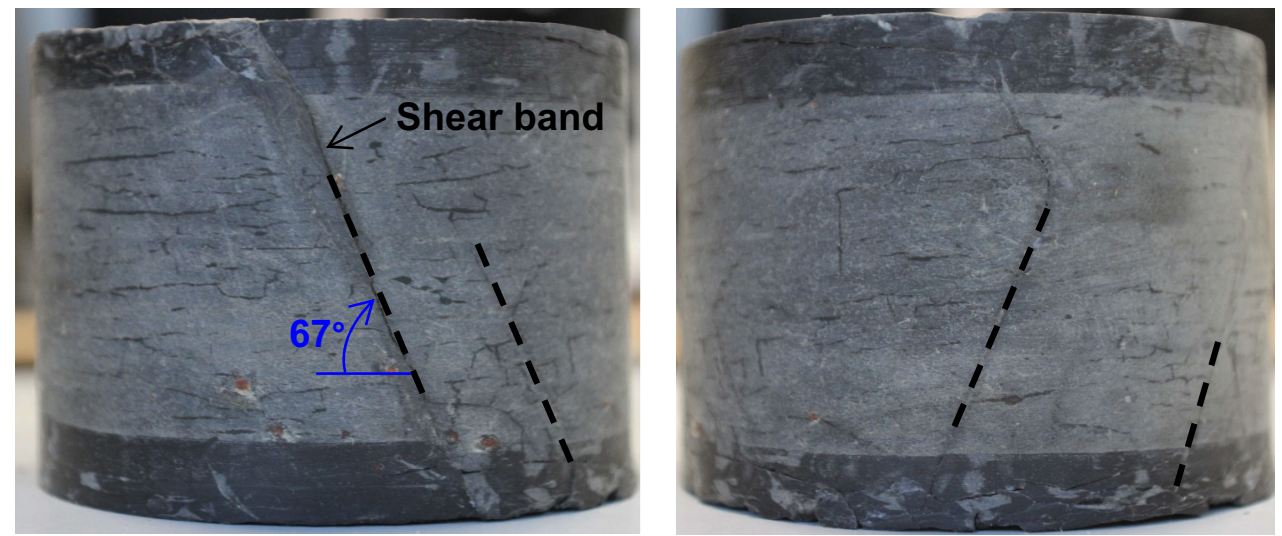

some shear bands. Unlike in other permeability tests, no satisfactory correspondence was observed between the responses of axial and radial LVDTs (Fig. 8c, d), with in particular opposite responses of the axial LVDTs. This confirms the mobilisation of shear planes and the relative movement of blocks during the permeability test.

Inspection of Fig. 8a shows that the outflow rate is maximal at the beginning of the test to afterwards decrease until the end of test at $18 \mathrm{~h}$. There is no initial inflow as observed previously, probably due to the presence of the recently developed shear bands that allow some water flow at the beginning. The progressive decrease of the outflow reflects the self-sealing behaviour of the shear bands, with the global permeability progressively coming back to a value of $6.9 \times 10^{-21} \mathrm{~m}^{2}$ quite comparable to that measured before shearing (3.2 and $5 \times 10^{-21} \mathrm{~m}^{2}$ ).

Figure 9 shows the results of a permeability test that was carried out after 2 days (point D). The response in terms of inflow and outflow is comparable to that observed at initial state with some effect of effective stress release at the beginning. The calculated value of radial permeability with $n=4$ is $3.7 \times 10^{-21} \mathrm{~m}^{2}$. These values are close to that of the sample before shearing. The specimen volume changes monitored by the water exchanges and LVDT measurements (Fig. 9b) are in good agreement and comparable to those obtained during the permeability test before shearing.

\subsection{Heating Under Undrained Conditions (Path D-} E)

At the end of the constant effective mean stress shear test at $25{ }^{\circ} \mathrm{C}$ under (path C-D) and after the permeability test, the shear stress $q$ value is $7.3 \mathrm{MPa}$, the confining pressure value is $6.6 \mathrm{MPa}$ and the back pressure 1.0 MPa. From this state, the vertical displacement of the piston was blocked by closing valve V1 (Fig. 1c). The confining pressure was kept constant at 6.6 MPa and the specimen was heated at a rate of $1{ }^{\circ} \mathrm{C} / \mathrm{h}$ under undrained conditions. Figure 10a shows the change in shear stress with respect to temperature. The shear stress first decreased from 7.3 to 7.1 $\mathrm{MPa}$ at $25.6{ }^{\circ} \mathrm{C}$ and afterwards increased up to a peak $(7.8 \mathrm{MPa})$ at $28.5^{\circ} \mathrm{C}$, followed by a progressive quasi-linear decrease to $5.3 \mathrm{MPa}$ at $80{ }^{\circ} \mathrm{C}$.

The changes in pore pressure during this path are presented in Fig. $10 \mathrm{~b}$ (up to $60{ }^{\circ} \mathrm{C}$ because a leak then occurred in the pressure transducers). One can observe that the pore pressure quickly increased from 1.0 to $1.5 \mathrm{MPa}$ when the temperature increased from 25.0 to $28.5{ }^{\circ} \mathrm{C}$, with a mean rate of $0.14 \mathrm{MPa} /{ }^{\circ} \mathrm{C}$. At temperature higher than $28.5^{\circ} \mathrm{C}$, the rate of pore pressure increase versus temperature increase became lower $\left(0.005 \mathrm{MPa} /{ }^{\circ} \mathrm{C}\right)$.

The changes in axial and radial strains with respect to temperature are presented in Fig. 10c. Below $28.5^{\circ} \mathrm{C}$, strains were negligible. Above $28.5^{\circ} \mathrm{C}$, the axial strain increased while the radial strain decreases. Axial strain data above $38{ }^{\circ} \mathrm{C}$ were unfortunately not monitored (no further change due to friction effects in the LVDT).

Examination of the inflow and outflow curves at $80{ }^{\circ} \mathrm{C}$ (Point E, Fig. 11a) evidences larger fluxes compared to previous tests. However, the intrinsic permeability value is equal to $2.4 \times 10^{-21} \mathrm{~m}^{2}$, a value comparable to that previously obtained before and after shearing. This confirms that the larger fluxes observed are due to the decrease in water viscosity $\mu_{\mathrm{w}}$ with temperature (from $8.90 \times 10^{-4}$ Pa.s at $25{ }^{\circ} \mathrm{C}$ to $3.55 \times 10^{-4} \mathrm{~Pa}$.s at $80{ }^{\circ} \mathrm{C}$ ) as already observed in the Boom clay (Monfared et al. 2012).

Figure $11 \mathrm{~b}$ shows the changes in sample volume during the test with good correspondence between water exchanges and LVDT measurements. A swelling of $0.087 \%$ is observed at the end of the test.

The subsequent cooling phase (path E-F) was performed at constant confining pressure $\left(\sigma_{3}=6.6 \mathrm{MPa}\right)$. During this phase, a leak in the application system of the shear stress led to a decrease in shear stress down to $0 \mathrm{MPa}$. The sample was then submitted to the combined 

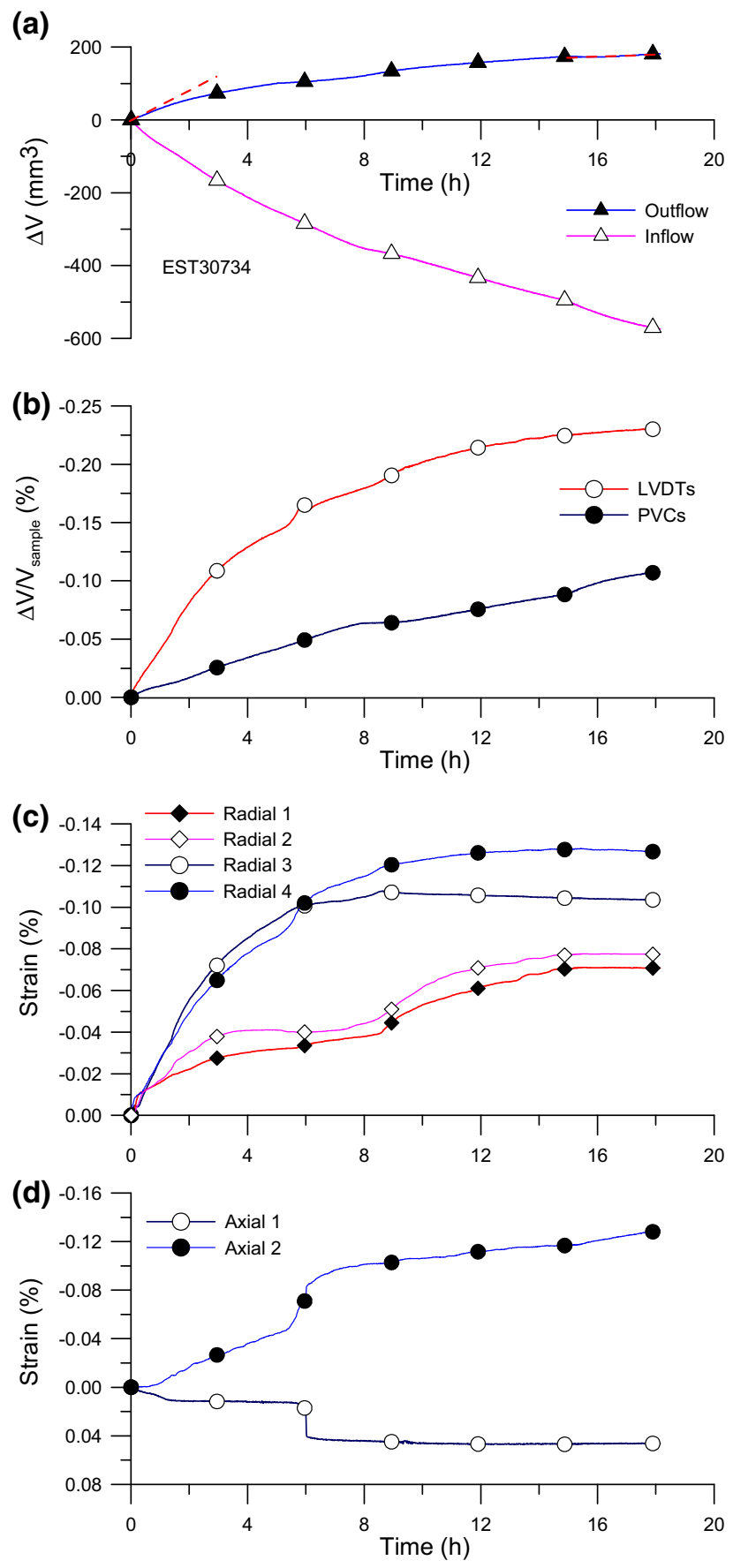

Fig. 8 Radial permeability test at point $\mathrm{C}$, a inflow and outflow, b volume change, $\mathbf{c}$ radial strains, $\mathbf{d}$ axial strains

effect of temperature decrease followed by shear stress release and it appeared difficult to analyse the resulting response to this poorly controlled thermo-mechanical stage.

The permeability test carried out at point $\mathrm{F}\left(25^{\circ} \mathrm{C}\right)$ provides a permeability value of $2.6 \times 10^{-21} \mathrm{~m}^{2}$ (Fig. 12a). As in previous tests, a swelling of $0.05 \%$ occurred (Fig. 12b).
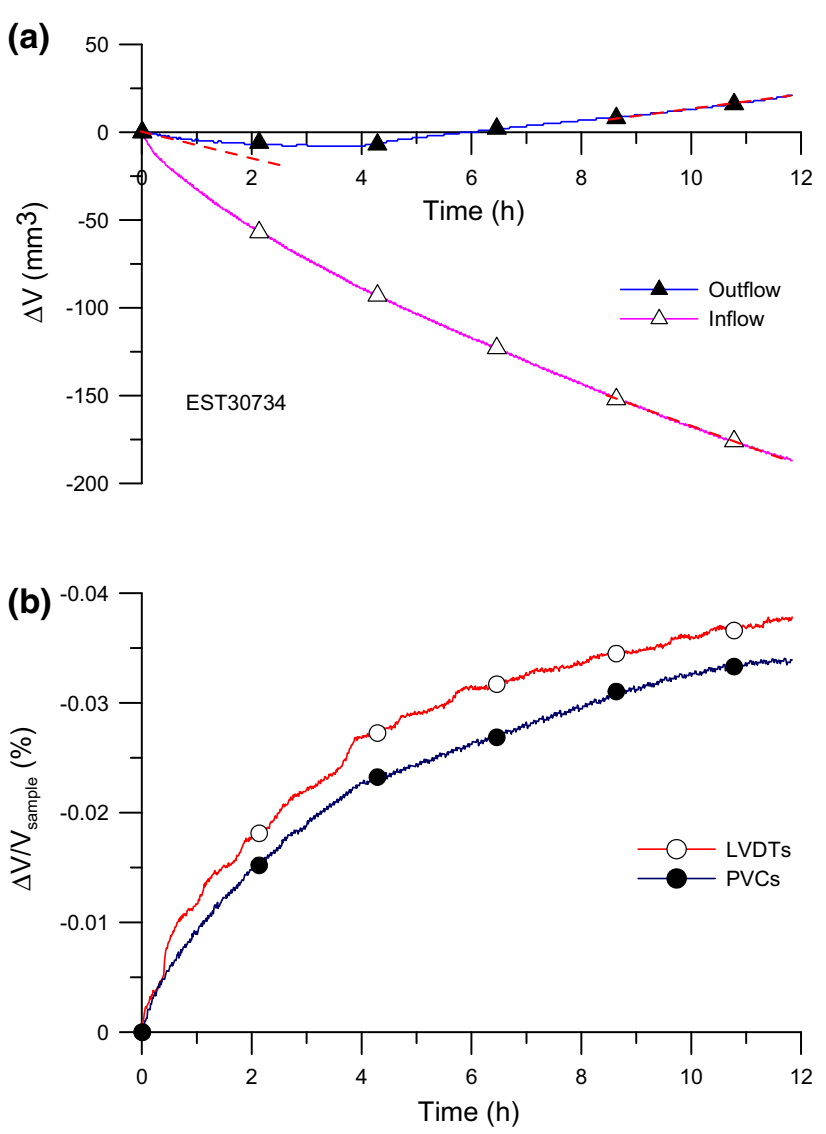

Fig. 9 Radial permeability test at point D, a inflow and outflow, b volume change

\subsection{Isotropic Drained Heating of the Sheared Sample (F-G)}

From point $\mathrm{F}$, the specimen was slowly heated up to $48{ }^{\circ} \mathrm{C}$ with a heating rate of $0.5^{\circ} \mathrm{C} / \mathrm{h}$, low enough to ensure drained conditions (Sultan et al. 2002; Monfared et al. 2011b). The local axial, radial and volumetric strains obtained from the LVDTs are presented in Fig. 13. Contraction of the sheared sample occurred from the beginning of the test, with radial strains larger than axial strains, showing some anisotropy in the thermal response. At $48{ }^{\circ} \mathrm{C}$, the axial strain is equal to $0.007 \%$ (characterised by a slope $C_{\mathrm{T} \perp}=0.28 \times 10^{-5}{ }^{\circ} \mathrm{C}^{-1}$ ) compared to $0.027 \%$ $\left(C_{\mathrm{T} \|}=1.26 \times 10^{-5}{ }^{\circ} \mathrm{C}^{-1}\right)$ for the radial strain.

\section{Discussion}

The test carried out in this work was aimed at further investigating some thermo-mechanical issues related to the behaviour of the excavation damaged zone that develops around galleries and repository cells excavated at great depth into a claystone. To do so, the first stage of the test 


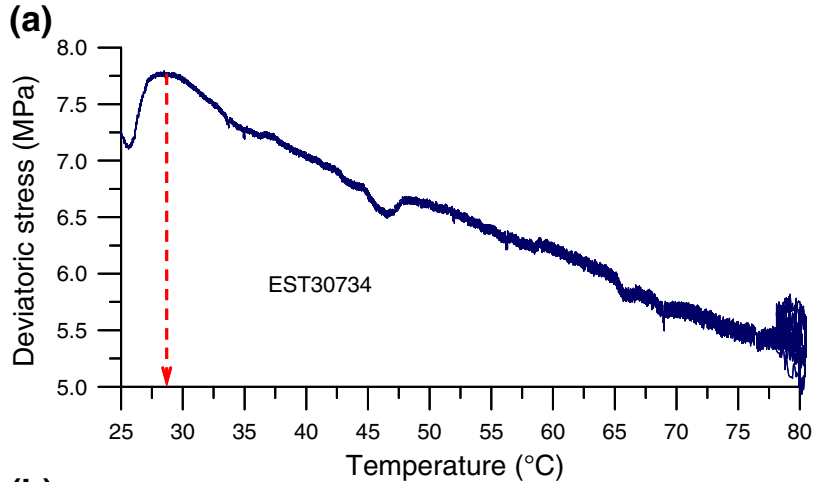

(b)

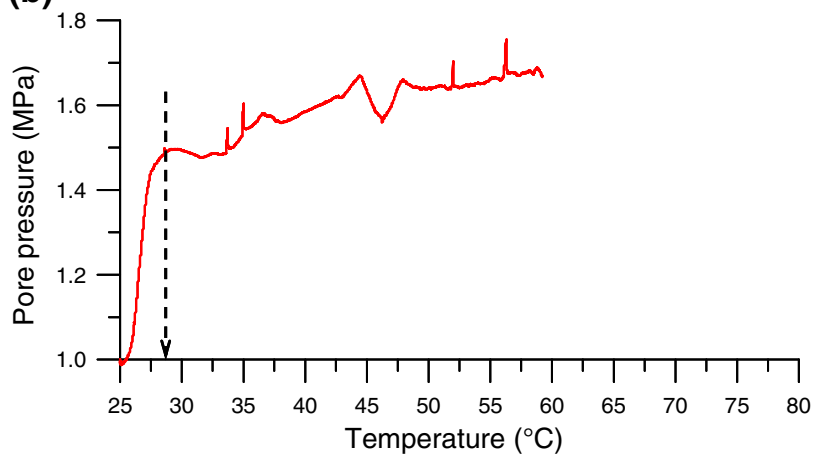

(c)

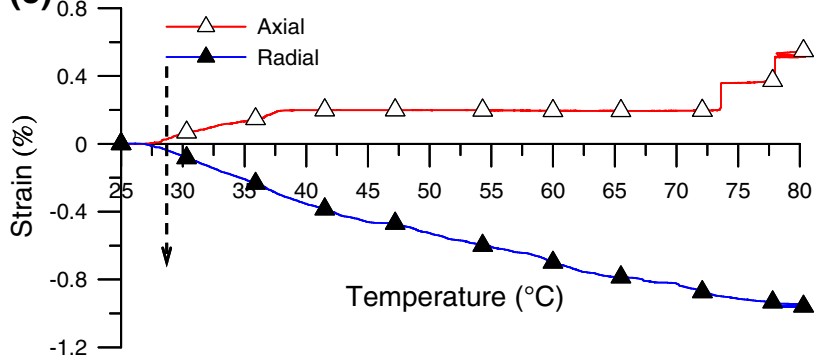

Fig. 10 Undrained heating test, a shear stress change, b pore pressure change, $\mathbf{c}$ axial and radial strains captured by LVDTs

was aimed at mimicking the stress path followed during excavation, by running a shear test at constant mean effective stress up to failure. This first stage carried out in drained conditions provided some insight into the shear strength and failure properties of the Callovo-Oxfordian claystone. As seen in Fig. 6 (path B-C-D), the curves obtained are comparable to other data obtained on the COx claystone, with axial strains (perpendicular to bedding) larger than radial ones (e.g. Chiarelli et al. 2003; Homand et al. 2003; Zhang and Rothfuchs 2004; Hu et al. 2014; Menaceur et al. 2015).

The corresponding stress path plotted in a $q-p^{\prime}$ diagram presented in Fig. 14 exhibits some small perturbations at the beginning of the test at low shear stress due to some technical problems with the PVC controlling the confining pressure, for $q$ values smaller than 1.0 MPa. The mean effective stress $p^{\prime}$ afterwards stabilises at $7.9 \mathrm{MPa}$. The Figure shows that failure is reached at a peak shear stress of
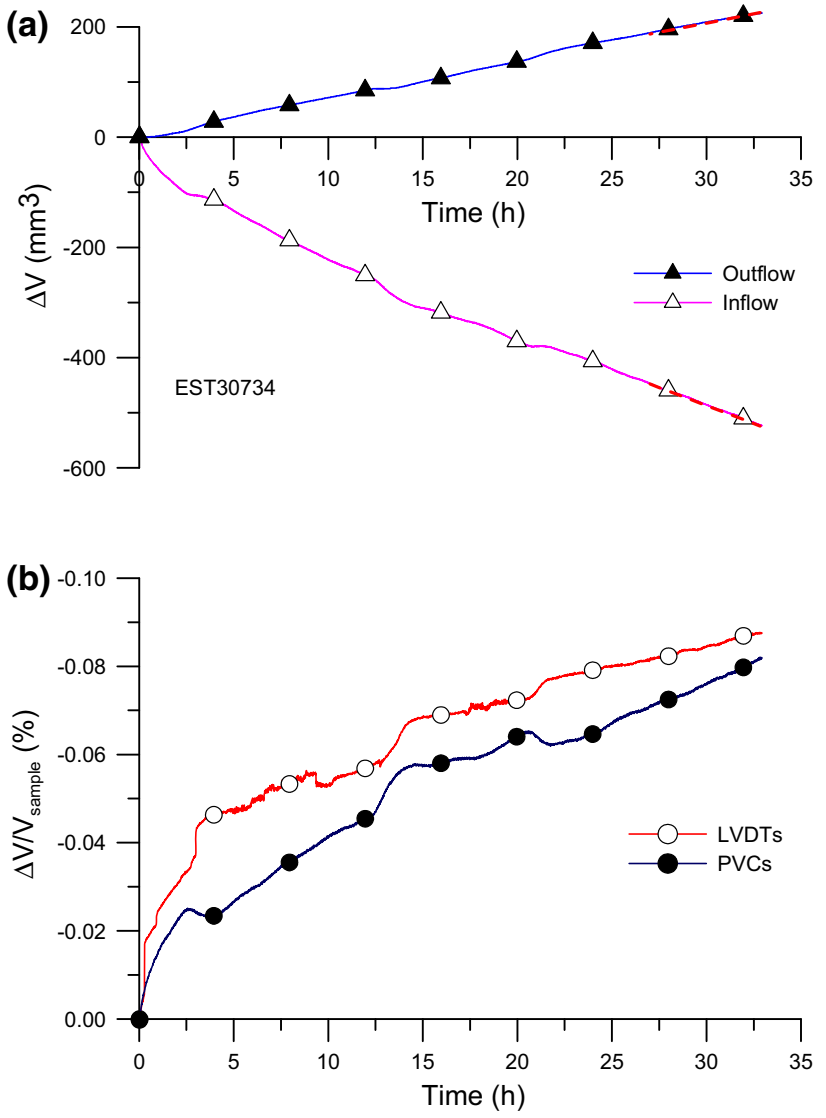

Fig. 11 Radial permeability test at point E, a inflow and outflow, b volume change

$11 \mathrm{MPa}$ (point $\mathrm{C}$ ). This is a rather small value compared to that obtained under comparable conditions by Zhang and Rothfuchs (2004) and $\mathrm{Hu}$ et al. (2014). This confirms the variability already observed in the failure criteria of the COx clay, that depends on the specimen origin and of the layer in which it has been excavated, together with other technical parameters like the experimental procedures followed (including the specimen size and shape, the resaturation procedure followed and the drainage conditions imposed). Visual observation made at the end of the test on the sheared specimen (Fig. 7) evidenced a shear network that obviously affected the post-peak response that was characterised by the mobilisation of the shear planes and the mutual sliding of blocks.

Particular attention was devoted to the changes in permeability along the various stages of the test to capture possible effects of strain localisation and temperature elevation on the overall response of the specimen. Permeability tests were carried out by running constant head steady state radial permeability tests in the hollow cylinder specimen, by imposing a pore pressure increase $(\Delta u=0.5 \mathrm{MPa})$ on the outer face of the cylinder while monitoring water exchanges using the pressure volume 

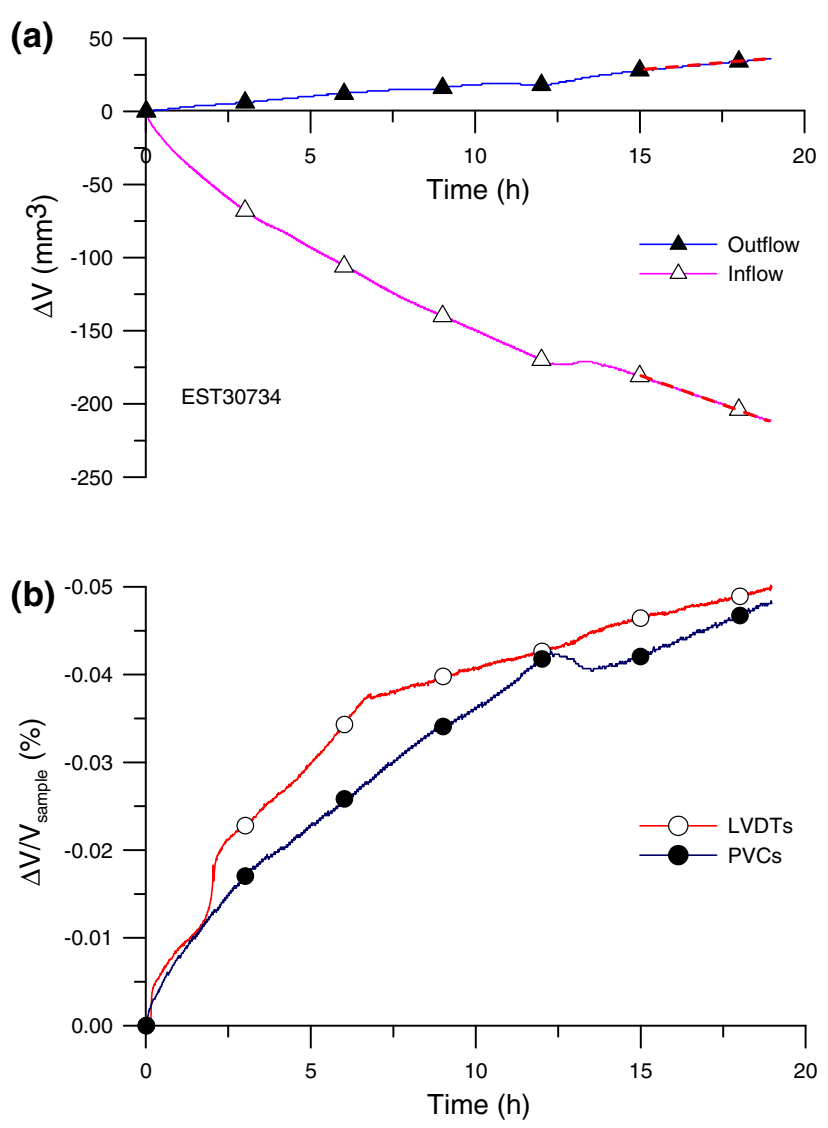

Fig. 12 Radial permeability test at point F, a inflow and outflow, b volume change

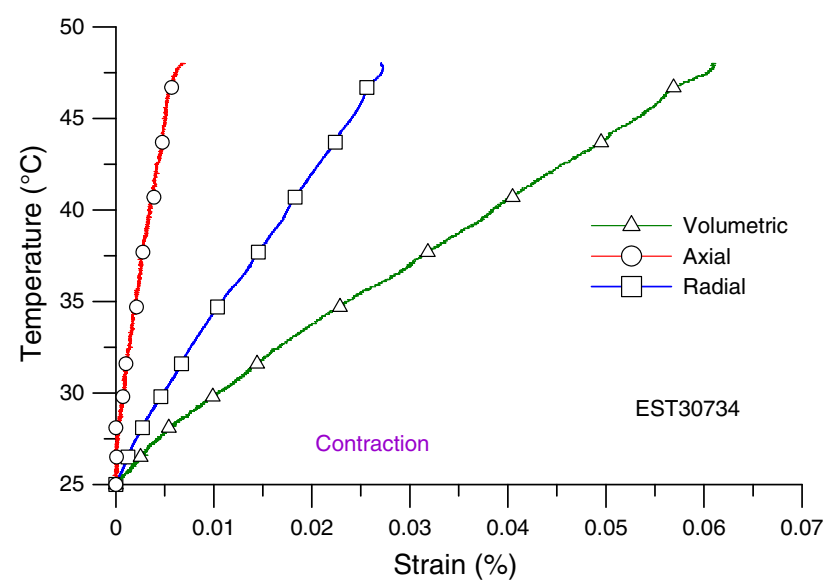

Fig. 13 Isotropic drained heating test

controllers. Unlike in standard triaxial testing on full cylinders that only involves an axial flow of water through the sample that may or may not be affected by a shear plane, the hollow cylinder configuration does impose a radial flow through the network of shear bands created at failure, in a direction parallel to bedding. It is hence particularly adapted to capture the effects of shear bands on

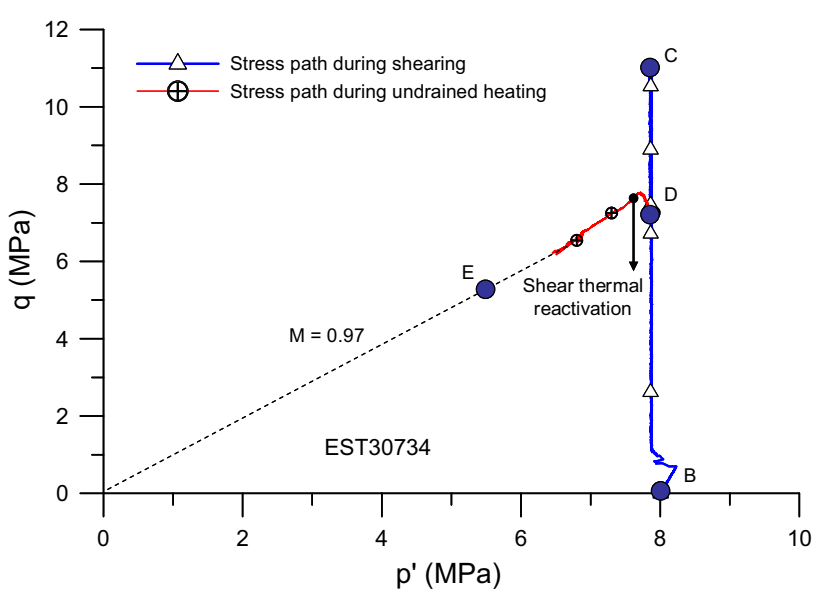

Fig. 14 Stress path in $q-p^{\prime}$ plane

the permeability. In this regard, this device usefully completes previous procedures carried out on sample in which tensile cracks were created (Davy et al. 2007). Both procedures then cover the water transfer properties of both the tensile and shear cracks that characterise the EDZ (Armand et al. 2014), allowing better investigation of the self-sealing properties of the claystone.

During permeability tests, the volume changes of the specimen were monitored by both the amount of water exchanges monitored by the PVC and the local strain measurements provided by the LVDTs. Quite a good correspondence was observed between these data in most tests, providing good confidence in the permeability values obtained. The combined effects of the effective stress release (progressively induced when applying the pore pressure increment of $0.5 \mathrm{MPa}$ on the outer face), the specimen hydration and the swelling induced, and the final stabilisation of water flows could clearly be identified in the curves of water exchanges provided by the PVC.

At the beginning of the test, a reference permeability value just after resaturation under conditions close to in situ stress $(p=9 \mathrm{MPa}$ and $u=1 \mathrm{MPa}$, point B) of $3.2 \times 10^{-21} \mathrm{~m}^{2}$ was obtained. This value is in the range of magnitude of intrinsic permeability of the COx claystone, estimated between $10^{-20}$ and $10^{-22} \mathrm{~m}^{2}$ (Escoffier et al. 2005; Delay et al. 2006; Mohajerani et al. 2011). Further changes due to shearing and temperature elevation could then be monitored by running similar tests at each stage of the test.

The 0.5 MPa excess pore pressure applied on the external face of the sheared sample induced a decrease in shear stress down to 7.3 MPa (path C-D) related to the reactivation of shear bands. The important conclusion drawn from the permeability test after this stage was that, in spite of the clear appearance of shear bands observed all around the sample (with a total of 21 bands all around the 
sheared specimen, see Fig. 7), they were no decrease in permeability at ambient temperature, confirming the good self-sealing properties of the COx claystone.

After the shear stress release phase, the undrained heating of the sheared sample exhibited a first stage up to a temperature of $28.5^{\circ} \mathrm{C}$ during which an increase in shear stress up to a peak at $7.75 \mathrm{MPa}$ was coupled to a fast increase in pore pressure up to a maximal value of 1.49 $\mathrm{MPa}$ (Fig. 10a, b) with no change detected in the LVDT measurements (Fig. 10c). During this stage in which the specimen was stable with no mobilisation of the shear planes, an estimation of the thermal pressurisation coefficient can be made.

The total pore pressure change during undrained heating is given from the water mass change equation $\left(\mathrm{d} M_{w}=0\right)$ as follows:

$\mathrm{d} u=B \mathrm{~d} p+\Lambda \mathrm{d} T$

where $B$ is the Skempton coefficient (Skempton 1954) and $\Lambda$ is the thermal pressurisation coefficient. Equation (2) indicates that the total pore pressure change is due to a part related to the total stress change $\left(B \mathrm{~d} p=B \frac{\mathrm{d} q}{3}\right)$ and a part related to temperature change $\left(\mathrm{d} u_{T}\right)$ :

$\mathrm{d} u_{T}=\Lambda \mathrm{d} T=\mathrm{d} u-B \frac{\mathrm{d} q}{3}$

The Skempton coefficient of saturated COx claystone was found equal to 0.87 (Mohajerani et al. 2014) for a saturated sample of same porosity $(17.7 \%)$ under in situ stress conditions $(p=12 \mathrm{MPa}, u=4 \mathrm{MPa})$. Given the poro-elastic expression of the $B$ coefficient:

$B=\frac{C_{\mathrm{d}}-C_{\mathrm{s}}}{C_{\mathrm{d}}-C_{\mathrm{s}}+\phi\left(C_{\mathrm{w}}-C_{\mathrm{s}}\right)}$

in which $\phi$ is the porosity and $C_{\mathrm{d}}, C_{\mathrm{s}}$ and $C_{\mathrm{w}}$ are the drained, solid and interstitial fluid compressibility, respectively.

One can observe that a slight change in Biot effective stress from 9.6 $\mathrm{MPa}(p=12 \mathrm{MPa}, u=4 \mathrm{MPa}$ with $b=0.6)$ to 8.4 $\mathrm{MPa}(p=9 \mathrm{MPa}, u=1 \mathrm{MPa}$ with $b=0.6)$ would mainly affect the $C_{d}$ drained compressibility coefficient. Given that the term $C_{d}$ is on top and bottom of the fraction, slight changes in $C_{d}$ should not significantly affect the $B$ value. As a consequence, a $B$ value of 0.87 is adopted here.

The pore pressure induced by the temperature increase can be calculated using Eq. (3), providing a thermal pressurisation coefficient equal to $0.156 \mathrm{MPa} /{ }^{\circ} \mathrm{C}$ between 25 and $28.5^{\circ} \mathrm{C}$. This value is in agreement with the results of Mohajerani et al. (2012) who observed that the thermal pressurisation coefficient slightly decreased with increased temperature, with a value of $0.145 \mathrm{MPa} /{ }^{\circ} \mathrm{C}$ at $32{ }^{\circ} \mathrm{C}$.

Once the peak reached at $28.5^{\circ} \mathrm{C}$, the shear stress started decreasing linearly while the increase in pore pressure became smaller and less regular. During this stage, the LVDT measurements evidenced a decrease in specimen length combined to an increase in radius, capturing the displacements resulting from the thermal reactivation of the shear bands and the mutual sliding of the blocks, in agreement with data obtained by Monfared et al. (2012) on the Boom clay. This reactivation resulted in a somewhat irregular response in pore pressure.

Due to thermal pore fluid pressurisation in the sheared sample and to the resulting decrease in effective stress during the undrained heating phase (D-F), the stress path moved towards the left. A continuous decrease in $q$ and $p^{\prime}$ was afterwards observed in the plane $q-p^{\prime}$ (Fig. 14) with a constant ratio $q / p^{\prime}$ equal to $M=0.97$, that corresponded to a friction angle $\phi^{\prime}=\arcsin \left(\frac{3 M}{6+M}\right)=24.7^{\circ}$. This value, that is typical of a residual state in which a pre-sheared plane is reactivated, is in good agreement with the results of Zhang and Rothfuchs (2004) at ambient temperature on the COx claystone. It would tend to indicate that the residual friction angle is not temperature dependent.

The sheared sample submitted to drained heating between 25 and $48{ }^{\circ} \mathrm{C}$ (path F-G, Fig. 13) exhibited a thermal contraction. Contraction is larger in the direction parallel to bedding than perpendicular to bedding, with an anisotropy ratio of 4.5. This trend is not in agreement with recent data of Monfared et al. (2011b, on the Opalinus clay) and of Mohajerani et al. (2014, on the COx claystone) who showed larger thermal contraction perpendicular to bedding. It is suspected here that the radial thermal contraction could be enhanced by the subvertical cracks (with an angle of $67^{\circ} \mathrm{C}$ with respect to horizontal, see the photo of the sheared specimen in Fig. 7) along which the smectite phase is mobilised. Note also that some mobilisation of the shear band could also intervene.

The permeability test run at $80{ }^{\circ} \mathrm{C}$ on the sheared sample showed that the intrinsic permeability of $\mathrm{COx}$ claystone was not dependent on temperature, with the larger fluxes observed only related to the decrease in water viscosity with temperature, in agreement with previous results on intact Boom clay sample (Delage et al. 2000). As already observed in the Boom clay and the Opalinus clay, the good self-sealing properties of the COx claystone are confirmed at elevated temperature.

\section{Conclusion}

An experimental programme was carried out in a new hollow cylinder triaxial cell with a short drainage path specially designed for low permeability rocks to investigate some thermo-hydro-mechanical issues in the EDZ around galleries excavated in claystones. The sample was first 
resaturated under a stress state close to in situ stress conditions to minimise swelling and damage during resaturation

To complete the understanding of the response of the EDZ around a gallery submitted to temperature elevation like that induced by exothermic radioactive waste, a COx specimen was submitted in the hollow cylinder triaxial apparatus to a stress path close to that supported in the close field during excavation, i.e. to shear at constant total mean stress. Once the sample sheared and the post-peak regime with shear bands reached, the shear stress was released. Subsequent undrained thermal pressurisation led to a decrease in mean effective stress that brought back the sheared sample to failure.

The results of radial permeability tests on COx claystone specimens showed an increase in the intrinsic permeability by 2 just after shearing that resulted in the development of a network of 21 shear bands around the sample. However, the permeability was afterwards rapidly reduced to a value comparable to the initial one, showing that shear bands did not affect the sample permeability and confirming the excellent self-sealing properties of the COx claystone. Like in the case of other clays and claystones, self-sealing properties are made possible thanks to the smectite fraction of the clay matrix that is mobilised along shear bands. The results of radial permeability test on heated samples already sheared evidenced the mobilisation of larger fluxes that were only due to the decrease in water viscosity with temperature, with no significant change in the intrinsic permeability. The results obtained here confirm the good self-sealing properties the COx claystone and extend them to elevated temperature.

Indeed, the presence of smectite minerals in the clays and claystones presently considered in Europe for the deep disposal of radioactive waste (the Boom clay in Belgium, the Opalinus clay in Switzerland and the Callovo-Oxfordian claystone in France) provide efficient self-sealing properties that result in the fact that the overall permeability of the EDZ is comparable to that of the intact rock. This point already evidenced in tensile cracks is now confirmed in shear cracks thanks to the special device used here.

Acknowledgments The authors are indebted to Andra, the French agency for the management of radioactive waste disposal, for funding this research and providing the specimens.

\section{References}

ANDRA (2012) Référentiel du comportement THM des formations sur le site de Meuse/Haute-Marne. D.RP.AMFS.1 2.0024

Armand G, Leveau F, Nussbaum C, De La Vaissière R, Noiret A, Jaeggi D et al (2014) Geometry and properties of the excavation- induced fractures at the Meuse/Haute-Marne URL drifts. Rock Mech Rock Eng 47:21-41

Bemer E, Longuemare P, Vincké O (2004) Poroelastic parameters of Meuse/Haute Marne argillites: effect of loading and saturation states. Appl Clay Sci 26(1):59-366

Bésuelle P, Viggiani G, Desrues J, Coll C, Charrier P (2014) A laboratory experimental study of the hydromechanical behavior of boom clay. Int J Rock Mech Rock Eng 47:143-155

Chiarelli AS, Shao JF, Hoteit N (2003) Modeling of elastoplastic damage behavior of a claystone. Int J Plast 19:23-45

Cui YJ, Le TT, Tang AM, Delage P, Li XL (2009) Investigating the time dependent behaviour of Boom clay under thermo-mechanical loading. Géotechnique 59(4):319-329

Davy CA, Skoczylas F, Barnichon JD, Lebon P (2007) Permeability of macro-cracked argillite under confinement: gas and water testing. Phys Chem Earth 32(8-14):667-680

Delage P, Sultan N, Cui YJ (2000) On the thermal consolidation of Boom clay. Can Geotech J 37(2):343-354

Delage P, Le TT, Tang AM, Cui YJ, Li XL (2007) Suction effects in deep Boom clay block samples. Géotechnique 57(1):239-244

Delay J, Trouiller A, Lavanchy JM (2006) Propriétés hydrodynamiques du Callovo-Oxfordien dans l'Est du bassin de Paris: comparaison des résultats obtenus selon différentes approches. Comptes Rendus Geoscience. 338(12):892-907

Escoffier S, Homand F, Giraud A, Hoteit N, Su K (2005) Under stress permeability determination of the Meuse/Haute-Marne mudstone. Eng Geol 81(3):329-340

Gaucher G, Robelin C, Matray JM, Négrel G, Gros Y, Heitz JF, Vinsot A, Rebours H, Cassagnabère Bouchet A (2004) ANDRA underground research laboratory: interpretation of the mineralogical and geochemical data acquired in the CallovianOxfordian formation by investigative drilling. Phys Chem Earth 29:55-77

Gens A, Vaunat J, Garitte B, Wileveau Y (2007) In situ behaviour of a stiff layered clay subject to thermal loading. Observations and interpretation. Géotechnique 57(2):207-228

Homand F, Chiarelli AS, Hoxha D (2003) Caractéristiques physiques et mécaniques du granite de la Vienne et de l'argilite de l'Est. Revue Française de Génie Civil 6(1):11-20

Hu DW, Zhang F, Shao JF (2014) Experimental study of poromechanical behavior of saturated claystone under triaxial compression. Acta Geotech 9:207-214

Hueckel T, Pellegrini R (1991) Thermoplastic modeling of undrained failure of saturated clay due to heating. Soils Found 31(3):1-16

Hueckel T, François B, Laloui L (2009) Explaining thermal failure in saturated clays. Géotechnique 59(3):197-212

Li Y, Weetjens E, Sillen X, Vietor T, Li X, Delage P, Labiouse V, Charlier R (2014) Consequences of the thermal transient on the evolution of the damaged zone around a repository for heatemitting high-level radioactive waste in a clay formation: a performance assessment perspective. Rock Mech Rock Eng 47:3-19

Menaceur H, Delage P, Tang AM, Conil N (2015) The thermomechanical behaviour of the Callovo-Oxfordian claystone. Int $\mathbf{J}$ Rock Mech Min Sci 78:290-303

Mohajerani M, Delage P, Monfared M, Tang AM, Sulem J, Gatmiri B (2011) Oedometric compression and swelling behaviour of the Callovo-Oxfordian argillite. Int $J$ Rock Mech Min Sci 48(4):606-615

Mohajerani M, Delage P, Monfared M, Tang AM, Sulem J, Gatmiri B (2012) A laboratory investigation of thermally induced pore pressures in the Callovo-Oxfordian claystone. Int J Rock Mech Min Sci 52:112-121

Mohajerani M, Delage P, Sulem J, Monfared M, Tang AM, Gatmiri B (2014) The thermal volume change of the Callovo-Oxfordian claystone. Int J Rock Mech Rock Eng 47:131-142 
Monfared M, Delage P, Sulem J, Mohajerani M, Tang AM, De Laure E (2011a) A new hollow cylinder triaxial cell to study the behaviour of geomaterials with low permeability. Int J Rock Mech Min Sci 48(4):637-649

Monfared M, Sulem J, Delage P, Mohajerani M (2011b) A laboratory investigation on thermal properties of the Opalinus claystone. Int J Rock Mech Rock Eng 44(6):735-747

Monfared M, Sulem J, Delage P, Mohajerani M (2012) On the THM behaviour of a sheared Boom clay sample: application to the behaviour and sealing properties of the EDZ. Eng Geol $124: 47-58$

Monfared M, Sulem J, Delage P, Mohajerani M (2014) Temperature and Damage Impact on the Permeability of Opalinus Clay. Int J Rock Mech Rock Eng 47:101-110

Morin R, Silva AJ (1984) The effects of high pressure and high temperature on some physical properties of ocean sediments. J Geophys Res 89(B1):511-526

Skempton AW (1954) The pore pressure coefficients A and B. Géotechnique 4:143-147

Sultan N, Delage P, Cui YJ (2002) Temperature effects on the volume change behaviour of Boom clay. Eng Geol 64(2-3):135-145
Wileveau Y, Cornet FH, Desroches J, Blumling P (2007) Complete in situ stress determination in an argillite sedimentary formation. Phys Chem Earth A/B/C 32(8-14):866-878

Yven B, Sammartino S, Geroud Y, Homand F, Villieras F (2007) Mineralogy, texture and porosity of Callovo-Oxfordian claystones of the Meuse/Haute-Marne region (eastern Paris Basin). Mémoires de la Société géologique de France 0249-7549(178):73-90

Zhang C (2011) Experimental evidence for the self-sealing of fractures in claystone. Phys Chem Earth 36:1972-1980

Zhang C (2013) Sealing of fractures in claystone. J Rock Mech Geotech Eng 5:214-220

Zhang C, Rothfuchs T (2004) Experimental study of the hydromechanical behaviour of the Callovo-Oxfordian argillite. Appl Clay Sci 26(1-4):325-336

Zhang C, Rothfuchs T (2008) Damage and sealing of clay rocks detected by measurements of gas permeability. Physics and Chemistry of the Earth A/B/C 33(Suppl. 1):S363-S373 